\title{
Importance of Body Condition Scoring in Reproductive Performance of Dairy Cows: A Review
}

\author{
Sayed Ahmad Nazhat, Amanullah Aziz*, Jahid Zabuli, Shahpoor Rahmati \\ Clinic Department, Faculty of Veterinary Science, Kabul University, Kabul, Afghanistan \\ Email: ^aziz_amanullah@yahoo.com
}

How to cite this paper: Nazhat, S.A., Aziz, A., Zabuli, J. and Rahmati, S. (2021) Importance of Body Condition Scoring in Reproductive Performance of Dairy Cows: A Review. Open Journal of Veterinary Medicine, 11, 272-288.

https://doi.org/10.4236/ojvm.2021.117018

Received: June 23, 2021

Accepted: July 25, 2021

Published: July 28, 2021

Copyright $\odot 2021$ by author(s) and Scientific Research Publishing Inc. This work is licensed under the Creative Commons Attribution International License (CC BY 4.0).

http://creativecommons.org/licenses/by/4.0/

\begin{abstract}
Body condition score (BCS) is a subjective method of assessing the amount of metabolizable energy stored in fat and muscle (body reserves) on a live animal. Body condition scores provide an indication of the energy status of dairy cattle. It can be used on both heifers and cows, although primarily they are used on the lactating dairy herd. Adjusting the nutritional program to obtain desired body condition at different stages of production is necessary to enhance production efficiency. Females that are too thin or too fat can be an expensive investment. Nutritional management is the most crucial one and is a key factor for normal production and reproduction cycle. Thus, it could be used as a management and selection tool to improve reproductive performance in dairy cows.
\end{abstract}

\section{Keywords}

Reproduction, BCS, Fertility, Cows

\section{Introduction}

The challenges associated with achieving maximum reproduction potential in modern high producing dairy cows have received considerable attention in recent times. In such scenario, delayed puberty and anestrous are one of the major constraints for optimal reproductive performance of dairy cows. Such condition besides imposing a question mark on the management practices, also prove to have unfavorable outcomes leading to reduced economic value of an animal.

The management system of measuring body condition has been used as a simple, accurate and clinically applicable tool to predict fertility during postpartum period in cows. It is useful to quantify the extent, as to which the various 
factors like nutrition, disease or other environmental causes, is significantly contributing towards determining the fertility status of the animal.

As time has passed, various methods of scoring body condition have evolved. Previously it was being done by conventional technique of measuring changes in weight or heart girth [1]. But due to the cumbersome and meagre interpretations, this system was soon outdated. Therefore, body condition scoring was originally developed for management in sheep during the 1960, before being adopted for use with cattle in the 1960s [2] [3] [4]. The scoring system was modified for beef cattle by Lowman et al. [5]. Later a criteria system created for BCS of dairy cattle [2] [6] [7]. During the last 25 years, various other BCS systems have been described and researched throughout the world [3].

With due course of time, some other subjective methods were standardized. These methods required expertise and were based on observation and palpation of certain parts of the animal body after which a score was given based on some standard numerical scale. Likely, there were some constraints in these methods too.

Palpation required animals to be under restraint while scoring was performed. For this reason, in many production systems, especially those with large herd sizes, the opportunity for this type of evaluation was limited. On the other hand, visual method is a preferred method when large numbers of freely moving cattle are involved. Body condition scoring performed in this way is a rapid and easy method of assessing the condition of cattle [8].

Similarly, like various methods to score an animal, the scale on which the score has to be decided varies with different conditions/individuals. A scale of 1 to 9 has been described for beef cattle and a scale of 1 to 5 is generally used for dairy cattle [9]. In both scales, score increases with the amount of fat deposits, mostly over the ribs, around the tail base, lumbar and pelvic areas, and gives a practical measurement of body reserves. Therefore, this system based on a fixed scale represents the state of the animal where the lower value represents extremely thin and the higher value signifies obese body condition.

BCS which gives a relative score to each cow for her level of body reserves in the form of muscle and fat is virtually very important as the BCS at key periods in lactation, as well as BCS changes over early lactation, could affect the resumption of estrous cycles and reproductive success [10].

Keeping in view the wide range which the scale represents, it should be realized that extremes of body condition, $<1.5$ or $>4$, will almost invariably reduce reproductive performance [10]. Low body after calving has been associated with increased incidence of anestrus and anovulatory cycles [11]. The cows with low BCS at breeding time have reduced estrus detection [12] and reduced fertility when enrolled in timed artificial insemination protocol [13].

Excessive BCS prior to calving has been recognized as a risk factor often associated with health problems and metabolic disorders e.g. retained placenta, metritis, ketosis, displaced abomasums and cystic ovaries [14] [15]. In wake of these 
facts, it is best to breed cows in good body condition and then use strategic supplementation with nutrients to get the desired production and reproduction traits.

Body condition scoring proves to be a wonderful tool in management. Not only it tempts to classify the animals into different categories representing their reproduction potential but also assists in managing them during the different phases of production in order to augment the fertility. The purpose of this chapter is to review the relationship between BCS and importance of it on reproductive performance.

\section{Evaluation of Body Condition Score}

Body condition score (BCS) is a subjective method of assessing the amount of metabolizable energy stored in fat and muscle (body reserves) on a live animal. BCS system initially developed by [16] for ewes. The system involved palpating the backbone and lumbar processes, feeling for the sharpness and covering of the bones. Ewes were scored on a scale from 0 to 5 , where 0 was on the point of death and 5 was very fat. Later, Lowman et al. [5] developed BCS system for beef cattle using a 0 to 5 scale, with intermediate values for animals whose condition falls between these numbers, functioning as an 11-point scale. This system also used palpation of the backbone and lumbar processes and included palpation of the tailhead region. Bullock et al. [17] suggested that for BCS to be considered as an indicator of body fat amount or percentage, it should be considered together with body weight (BW) and frame. However, Broster and Broster [18] suggested that BCS reflects largely adipose tissue stores and no protein reserves. For this reason, BCS together with body weight (BW) can be proposed to be good predictors for body fat [19] [20] [21]. Among others, Edmonson et al. [22] and Ferguson et al. [11] indicated that not only is BCS a good measure of total body fat but also the method is accurate and repeatable between assessors of body condition. In many countries, a system of charts, pictures and descriptions to define specific characteristics of each BCS [23] [24] has been developed.

Bullock et al. [17] suggested that for BCS to be considered as an indicator of body fat amount or percentage, it should be considered together with body weight (BW) and frame. However, Broster and Broster [18] suggested that BCS reflects largely adipose tissue stores and no protein reserves. For this reason, BCS together with body weight (BW) can be proposed to be good predictors for body fat [19] [20] [21]. Among others, Edmonson et al. [22] and Ferguson et al. [11] indicated that not only is BCS a good measure of total body fat but also the method is accurate and repeatable between assessors of body condition.

Some workers have defined a separate scale of 1 to 9 for beef cattle [25] and a scale of 1 to 5 is for dairy cattle [26]. Whereas some workers use the same measurement scale with similar results in both types [27]. In both scales, score increases with the amount of fat deposits and gives a practical measurement of body reserves. Others have further, aided their measurements by using calipers 
[28]. Moreover, this technique requires expertise and because of the subjective nature of body condition scoring its perception varied among individuals. However, to make BCS more practical and for situations where it is not possible to palpate the animals, many workers [9] [22] proposed visual method which became a preferred method in large dairy farms.

In many countries, a system of charts, pictures and descriptions to define specific characteristics of each BCS [23] [24] has been developed. Body condition scoring performed in this way is a rapid and easy method of assessing the condition of cattle without the use of scales and is relatively unaffected by body size [8]. Critical times to monitor body condition score of the cowherd are 30 days prior to breeding, 90 days post-breeding, weaning, 100 days prior to calving and at calving.

\section{Criteria of Score}

The interpretation of the score remains constant all over the world. Too low or too high score was found to be detrimental to the fertility status of the animal. Thus, it is necessary for a cow to be in appropriate body condition for optimum reproductive function.

The evaluation of body scoring has been extensively studied and desirable scores have been recommended for cows [22] [24] [29] [30] and buffaloes [31]. Body condition score 1.0 indicates a very thin cow. A body condition of 2.0 is also too thin. Such cows may be in good production status but their reproduction may suffer from lack of body condition. Ideally, no cow in a herd should be less than 2.0. A body condition score of 3.0 indicates the ideal condition for cows in mid-lactation. These cows are supposed to have passed the stage of negative energy balance, have been gaining weight for several weeks and have begun to accumulate flesh covering the hooks, pins and vertebrae. If a cow is halfway between 2 and 3, then her body condition score is considered to be 2.5. Less than 10 percent of the herd should score 2.5 or below. A body condition score of 4.0 indicates a cow that is heavy at calving or is getting ready to go dry. Generally, cows should not score above 4.0 because then they are considered fat and it can interfere with reproduction as well as can depress their appetite. If a cow scores above 4.0 , then she is considered very fat. If she scores 5.0, then she is deemed to be an obese cow which is at high risk for many metabolic problems, decreased fertility and is more prone to go off feed at the time of calving. Essentially, a cow with a 5.0 body condition score is round and covered with fat.

\section{Relation of Dry Matter Intake Energy Balance and BCS in Reproductive Performance}

Management of reproductive performance, including both fertility and calving, is an important issue to the dairy industry. The primary goal of commercialized dairy farming not only pertains to birth of a calf per year but also sustenance of a viable economics in terms of variable inputs and the consequential results. These 
inputs incur heavy investment in terms of many factors like infrastructure, labour, feed, medicines, etc. Out of all these, nutritional management is the most crucial one and is a key factor for normal production and reproduction cycle. Its relationship with reproduction has been established [32].

The nutritional status or energy balance of an animal is evaluated through body condition score (BCS), as it reflects the body energy reserves available for metabolism, growth, lactation and activity [33]. It is an important managemental tool for maximizing milk production and reproductive efficiency while reducing the incidence of metabolic and other peripartum diseases. In addition, assessment of body condition scores (BCS) of dairy cattle can be an accurate way of evaluating the effectiveness of dairy feeding systems. Body condition score changes throughout the lactation cycle and gives an idea about the cow's energy balance and its feeding requirements [34]. The need for estimating the body condition score has amplified in the last few years, especially when the problem of decreased fertility due to nutrition was documented by several authors [35]. Loeffler et al. [36] established that negative energy balance, body condition loss and disease affect fertility.

\section{Relation of Dry Matter Intake (MI) and BCS during Prepartum Period}

Nutritional status in the prepartum period influences subsequent reproductive performance [33]. Dry matter intake and negative energy balance during the dry period have a crucial influence on herd health, productivity and reproductive efficiency. They affect endocrine parameters, metabolic hormones and key concentrations of metabolic factors. There is normal decline in DMI prepartum in cows, as the foetus grows, which is exacerbated in cows that subsequently develop metabolic or gynaecological problems at or after parturition [34]. Thus, excessive drop in DMI prepartum could serve as an early warning signal of the propensity of cows to develop problems at or after parturition as inadequate protein and energy intake during pregnancy results in low BCS at calving [37].

In cows, both, an excessive ( $\geq 4.0$ points, scale $1-5)$ or insufficient $(<2.0$ points) BCS at calving reduces subsequent fertility rates. In addition, loss or gain of one BCS after calving significantly reduced fertility in cows with acceptable BCS before parturition [38] and affected the general health status of the animal [39]. Gearhart et al. [29] demonstrated that cows losing more body condition during the dry period were at a higher risk for dystocia. This, in turn, means these cows are more likely to be culled for infertility.

On the other hand, over-conditioned cows (BCS > 3.5) have reduced DMI post-calving, lose excess BCS post-calving, have lower fertility and increased risk of developing cystic follicles [40]. Thus, it becomes increasingly clear that massive increases in BCS followed by abrupt loss in the early postpartum period are not well tolerated by the cow [41].

Current strategies to minimize BCS loss involve keeping cows in BCS 2.75 - 
3.00 at calving, shortening the dry period and maintenance of normal rumen function. Thus, minimizing BCS changes pre and post-calving, maintenance of optimal rumen function and prevention strategies to prevent metabolic disorders are key management targets, in association with improved cow comfort and reduced stress, to improve health, productivity and reproductive efficiency of high yielding dairy cows [40]. Furthermore, feeding high roughage diets at the start of the dry period to minimize BCS gain and maintaining change in BCS score of 0.5 of a unit are increasingly important goals to achieve for high conception rates and herd pregnancy rates [42].

\section{Over Conditioned at Calving}

In dairy herds, the BCS at calving is tightly related to milk yield [43] [44]. However, in beef herds, the prepartum BCS, the BCS change during pregnancy and the calving BCS do not generally affect milk yield or calf performance [45] [46] [47] [48]. The most consistent relationship among published studies has been the increased incidence of ketosis for cows with high BCS at calving [49]. Gillund et al. [50] described a cow with a score as high or higher than 3.5 was approximately 2.5 times more likely to become ketotic than cows with scores at calving as low or lower than 3.25. In addition, it was reported that ketotic cows had higher BCS at calving and during the first weeks postpartum than healthy cows and lost significantly more body condition over a prolonged period of time compared with non-diseased cows. Similarly, Gillund et al. [50] reported that cows calving with BCS 3.75 are at higher risk of developing ketosis with a subsequent lower likelihood of becoming pregnant at first breeding. For likelihood of retained placenta or metritis, Markusfeld et al. [51] calculated an odds ratio of 0.7 for each additional unit of BCS at calving, indicating that cows with higher BCS at calving were less likely to experience retained placentas.

\section{Postparturient Transition Period and BCS}

High yield in the early postpartum period forces the cow to mobilize mainly fat but also protein to meet the energy demands of milk production. During that period, a cow can lose up to $50-75 \mathrm{~kg}$ of body weight with no adverse effect [40]. The duration of this steep fall can be shortened and prevented by increasing DMI in the early postpartum period as not only this sharp body condition loss affects the production level of the animal but also makes it prone to many other grave conditions [52].

Optimal body condition of dry cows should be between scores 3.00 and 3.75. Risk of problems can be avoided when cows have scores from 3.25 to 3.50. In early lactation, cows loose body condition. Body condition lost during this period can be maximum 1.00 unit of BCS.

Cows that are mobilizing tissue at a high rate have increased blood concentration of non-esterified fatty acids, $\beta$ hydroxy butyrate, triacylglycerol but reduced concentrations of insulin, glucose and IGF-I [34]. This metabolic status increases 
the risk of hypocalcaemia, acidosis, ketosis, fatty liver, metritis and displaced abomasums [42] [53] [54]. Butler and Smith [55] reported significantly higher incidence of metritis in cows losing 0.5 to $1.0 \mathrm{BCS}$ units (22\%) or $>1.0 \mathrm{BCS}$ units (47\%) when compared with cows losing $<0.5$ BCS units (6\%). In another study, cows with BCS at calving $<3.0$ were more likely to have metritis than cows with a higher BCS at calving [56]. Waltner et al. [57] failed to identify a relationship between BCS and metritis.

Other studies show that delayed conception can be related to sub-clinical disease, stressful environmental, social conditions and nutritional stress [57]. Thus, it is clear that inadequate nutritional management of the cow in the dry period and after calving has a significant negative impact on subsequent conception rate, services per conception and interval from calving to conception.

After calving, dairy cows experience a slow increase in dry matter intake, a rapid increase in milk production and increased mobilization of fat tissue [58]. It is thus important for the dairy cows to maintain adequate body condition prior to calving as after calving, as cows increase in milk producing ability. It is usually 50 to 60 days after calving before they are in a positive energy balance.

\section{Postpartum Anestrus and BCS}

It is a worldwide recognized fact that, in the postpartum cow there is a normal anestrus period. Delayed recovery of ovarian activity is associated with poor body condition at calving. This situation appears when feed intakes in the last third of gestation are insufficient. Practically for multiparous is no real effect of BCS at calving on the cyclicity, but a significant effect of the postpartum state loss was determined [59]. According Freret et al. [60], cows that lost more than 1.5 points of their BCS between 0 and 60 days postpartum are characterized by nocyclicity or prolonged luteal phase. Pivko et al. [61] indicated that a poor body condition (mainly BCS 1 ) in cows may even result in the malfunction of ovarian activity in the form of cystic atresia of ovarian follicles. There is a close relationship between the cow body condition traits not only from the viewpoint of animal husbandry parameters, but also in the relationship to ovarian activity Bezdicek et al. [62]. However, this period is considered as abnormal when it extends beyond an average of 90 days [63]. Prolonged postpartum periods of anestrus ( $>150$ days), due to its great incidence, is one of the main infertility problems [64]. Postpartum anestrus is more marked in beef cattle [65] and is a main factor limiting reproductive efficiency, because it prevents achievement of a 12-month calving interval.

Studies indicate that cows with lower body condition scores and loss of weight have lower conception rates and decreased efficiency of heat detection, compared to cows that are gaining weight and have higher body condition scores. Low BCS at calving leads to delay in onset of estrus, reduced fertility [66] and a longer inter-calving period in cows [37]. Wright et al. [67] indicated that each BCS is equivalent to $53 \mathrm{~kg}$ of body weight in cows and that postpartum anestrus 
extended 43 days for each BCS lost at calving. The condition worsens when the cows have poor body condition because they suffer more from adverse effects of negative energy balance as they are not able to meet the energy requirements for growth, maintenance and milk production [68]. Gearhart et al. [29] determined that cows at dry off $(\geq 4.0)$ had 2.5 times the risk of cystic ovaries in the next lactation than cows in good condition at dry off. In another study, cows with higher BCS were likely to have inactive ovaries than cows with lower BCS [51]. In the same studies, cows that lost more BCS during the dry period were 2.1 times more likely to have inactive ovaries for each additional BCS unit lost.

Though some authors [69] [70] have noticed a significant positive relationship between mean energy balance in the first weeks after calving and interval to first ovulation, still many others [71] [72] have found no relationship between mean negative energy balance and duration of postpartum anoestrus. Lucy et al. [73] reported that increasing energy balance is proportional to the number of large follicles in postpartum dairy cows. Prado et al. [74] found significant differences in follicular development related to body condition. Cows loosing $\geq 1$-unit BCS after calving had a prolonged interval to commencement of luteal activity and were at greater risk of having delayed first ovulation. Sharestha et al. [75] stated poor postpartum nutritional status to be associated with delayed first ovulation postpartum. Butler et al. [69], Canfield et al. [76] and Canfield and Butler [77] found that first ovulation occurred approximately 10, 14 and 14 days after the maximum negative energy balance, respectively. Therefore, Fernando et al. [78] [79] shown that the nutritional status of the female animal affects growth and follicular diameter, follicle maturation and ovulation. In another study [80] suggested that the body condition and therefore nutrition and follicle size, had a specific effect on the proportion of cows that ovulate. It has been accepted that the nutrition acts at various levels of the system that monitored reproduction and that the main pathway by which nutrition affects follicular development is through the hypothalamic pituitary ovarian axis [81]. Rasby et al. [82] shown that the administration of a diet with low protein and energy content influence negatively the LH concentration, and therefore affect the growth, persistence and ovulation of the dominant follicle. Fernando et al. [78] found that body condition has no effect on beef cows on estrus traits, but there results agree to those observed in other cattle breeds, and also suggested that body condition affected follicle development and ovulation rate. Zurek et al. [83] further added that when ovulation occurred, energy balance was still negative but, in all cases, it was in a decreasing status.

Dubuc et al. [84] show in their study that the early ovulation or prolonged anovulation was associated with indicators of negative energy balance and uterine inflammation during the peripartum period. They also determined that ovulation by 21 DMI was associated with shorter time to pregnancy and prolonged anovulation was detrimental to subsequent reproductive performance and culling. However, the loss in BCS during the postpartum period appears to 
have a strong relationship with first service conception rate, whereas the absolute BCS at calving does not [85]. Butler and Smith [55] found that cows which lost less than 0.5 units of BCS during the first 5 weeks postpartum had higher conception rates at the first service than cows that lost more than $0.5 \mathrm{BCS}$. Domecq et al. [44] concluded that multiparous cows that lost 0.40 and 0.80 points of BCS were respectively 0.85 and 0.47 times more likely to conceive at first service than cows that did not lose BCS. Suriyasathaporn et al. [86] concluded that cows with BCS 2 - 2.75 after 45 days interval milking (DIM) were more likely to conceive at first service than cows with $\mathrm{BCS}<2$ or $\mathrm{BCS} \geq 3$.0. Increased losses in BCS were associated with decreased risk of conception.

In another study [86] recorded that BCS at first insemination was not significant but the loss in BCS during the first 100 days of lactation was significant with cows losing more BCS being less likely to conceive. Ferguson and Otto [87] showed that first service conception rate progressively decreased from $55.9 \%$ for cows losing 0.51 to 1.0 unit of BCS to $28.6 \%$ for cows losing > 1.0 unit of BCS from calving to breeding. Further, cows with BCS 3.75 to 4.25 prepartum had higher conception rates than cows with BCS $\geq 3.5$ [85]. Buckley et al. [88] demonstrated that cows with a low BCS had reduced conception rates compared with cows with moderate or high BCS. Roche et al. [89] demonstrated that cows with lower BCS at first service significantly affected pregnancy at first service. Patton et al. [90] showed that cows with lower BCS at first service had significantly lower conception rates. Garnsworthy and Topps [91] showed that cows calving at a medium BCS (3.25 to 3.75) had significantly fewer services per conception than cows with high or low BCS in trail. Hegazy et al. [92] determined that the number of services per conception was lower for cows scoring $\leq 1.5$ or 2.0 at first service than for cows with BCS $\geq 2.5$.

Braun et al. [93] observed days open to be significantly lower for cows with moderate BCS at calving (3.0 to 3.5), pre-breeding (2.5 to 3.0) and peak milk (3.0 to 3.5) as compared with cows with higher or lower BCS. Ruegg et al. [94] showed that cows with BCS $<3.5$ at calving had fewer days open cows with BCS $\geq$ 3.5 at calving. In primiparous cows, [51] reported that the calving interval was 6.3 days shorter for each additional unit of BCS at calving.

Hegazy et al. [92] reported that days open decreased significantly for each BCS at service interval up to score 3.0. Fagan et al. [95] demonstrated that cows with a BCS $<2.5$ had longer calving intervals than those with a $\mathrm{BCS} \geq 2.5$. Wathes et al. [96] noted that cows with a BCS $\geq 3.0$ took 3 weeks longer to conceive than cows with a BCS of 2.75 to 3.5 . In another study, lower BCS nadir significantly increased days open [90].

Thus, BCS is an effective management tool for evaluating the energy reserves of cows and the whole nutritional program throughout the year. Here, condition scoring of cattle allows the dairy keepers to determine if their cows are thriving in the system of management they are kept under and what steps need to be taken to strike a balance for good productive and reproductive results. Body 
condition scores (BCS) allow producers, extension personnel and researchers to communicate more effectively regarding the herd's nutritional requirements.

\section{Conclusion}

In conclusion, impaired fertility is one of the main limiting factors affecting economy of dairy industry. Most studies have identified that BCS is a useful tool to aid in management of dairy cows as a proxy for estimating energy balance and risk factors for diseases. Those cows have over condition where at higher risk of developing metabolic diseases with subsequent lower likelihood of becoming pregnant at first breeding. Low BCS at calving leads to delay in onset of estrus, delayed follicular development, reduced fertility and longer inter calving period. The relationship of nutrition and management with fertility has been well recognized.

\section{Conflicts of Interest}

The authors declare no conflicts of interest regarding the publication of this paper.

\section{References}

[1] Nicholson, M.J. and Butterworth, M.H. (1986) A Guide to Condition Scoring of Zebu Cattle. International Livestock Centre for Africa, Addis Ababa, 1-29.

[2] Earle, D.F. (1976) A Guide to Scoring Dairy Cows Condition. Journal of Agriculture, Victoria, 74, 228-231.

[3] Bewley, J.M. and Schutz, M.M. (2008) Review: An Interdisciplinary Review of Body Condition Scoring for Dairy Cattle. The Professional Animal Scientist, 24, 507-529. https://doi.org/10.15232/S1080-7446(15)30901-3

[4] Bell, M.J., Mareike, M., Marison, S. and Robert, P. (2018) Comparison of Methods for Monitoring the Body Condition of Dairy Cows. Frontiers in Sustainable Food Systems, 2, Article No. 80. https://doi.org/10.3389/fsufs.2018.00080

[5] Lowman, B.G., Scott, N.A. and Somerville, S.H. (1976) Condition Scoring of Cattle. East of Scotland College of Agriculture. Animal Production, Advisory and Development Department Edinburgh: Edinburgh School of Agriculture Bulletin, No. 6.

[6] Mulvany, P.M. (1977) Dairy Cow Condition Scoring. National Institute for Research in Dairying. Paper No.4468. Shinfield, Reading.

[7] Mulvany, P.M. (1981) Dairy Cow Condition Scoring. BSAP Occasional Publication, 4, 349-353. https://doi.org/10.1017/S0263967X00000690

[8] Grainger, C., Wilhelms, G.D. and McGowan, A.A. (1982) Effect of Body Condition at Calving and Level of Feeding in Early Lactation on Milk Production of Dairy Cows. Australian Journal of Experimental Agriculture and Animal Husbandry, 22, 9-17. https://doi.org/10.1071/EA9820009

[9] Wildman, E.E., Jones, G.M., Wagner, P.E., Boman, R., Troutt, H.F. and Lesch, T.N. (1982) A Dairy Cow Body Condition Scoring System and Its Relationship to Selected Production Characteristics. Journal of Dairy Science, 65, 495-501. https://doi.org/10.3168/jds.S0022-0302(82)82223-6

[10] Pryce, J.E., Coffey, M. and Simm, G. (2001) The Relationship between Body Condition Score and Reproductive Performance. Journal of Dairy Science, 84, 1508-1515. 
https://doi.org/10.3168/jds.S0022-0302(01)70184-1

[11] Ferguson, J.D., Galligan, D.T. and Thomsen, N. (1994) Principal Description of Body Condition Score in Holstein Cows. Journal of Dairy Science, 77, 2695-2703. https://doi.org/10.3168/jds.S0022-0302(94)77212-X

[12] Santos, J.E., Villasenor, M., Depeters, E.J., Robinson, P.H. and Holmberg, C.H. (2003) Type of Cotton Seed and Gossypol in Diets of Lactating Dairy Cows: Plasma Gossypol, Reproduction and Health. Journal of Dairy Science, 86, 892-905. https://doi.org/10.3168/jds.S0022-0302(03)73672-8

[13] Moreira, F., Risco, C., Pires, M.F.A., Ambrose, J.D., Drost, M. and DeLorenzo, M. (2000) Effect of Body Condition on Reproductive Efficiency of Lactating Dairy Cows Receiving a Timed Insemination. Theriogenology, 53, 1305-1319. https://doi.org/10.1016/S0093-691X(00)00274-0

[14] De Vries, M.J. and Veerkamp, R.F. (2000) Energy Balance of Dairy Cattle in Relation to Milk Production Variables and Fertility. Journal of Dairy Science, 83, 62-96. https://doi.org/10.3168/jds.S0022-0302(00)74856-9

[15] Hutchinson, J.L. (2002) Troubleshooting Infertility Problems in Dairy Cattle. In: Dairy Integrated Reproductive Management. Pennn State Extension, Collage of Agricultural Sciences, The Pennsylvania State University, IRM-19 207, 1-4.

[16] Jefferies, B. (1961) Body Condition Scoring and Its Use in Management. Tasmanian Journal of Agriculture, 32, 19-21.

[17] Bullock, K.D., Bertrand, J.K., Benyshek, L.L., Williams, S.E. and Lust, D.G. (1991) Comparison of Real-Time Ultrasound and Other Live Measures to Carcass Measures as Predictors of Beef Cow Energy Stores. Journal of Animal Science, 69, 3908-3916. https://doi.org/10.2527/1991.69103908x

[18] Broster, W.H. and Broster, V.J. (1998) Body Score of Dairy Cows: Review. Journal of Dairy Research, 65, 155-173. https://doi.org/10.1017/S0022029997002550

[19] Gresham, J.D., Holloway, J.W., Butts, W.T. and McCurley, J.R. (1986) Prediction of Mature Cow Carcass Composition from Live Animal Measurements. Journal of Animal Science, 63, 1041-1048. https://doi.org/10.2527/jas1986.6341041x

[20] Waltner, S.S., McNamara, J.K., Hillers, J.K. and Brown, D.L. (1994) Validation of Indirect Measures of Body Fat in Lactating Cows. Journal of Dairy Science, 77, 2570-2579. https://doi.org/10.3168/jds.S0022-0302(94)77198-8

[21] Coffey, M.P., Simm, G. and Brotherstone, S. (2002) Energy Balance Profiles for the First Three Lactations of Dairy Cows Estimated Using Random Regression. Journal of Dairy Science, 85, 2669-2678. https://doi.org/10.3168/jds.S0022-0302(02)74352-X

[22] Edmonson, A.J., Lean, I.J., Weaver, L.D., Farver, T. and Webster, G. (1989) A Body Condition Scoring Chart of Holstein Dairy Cows. Journal of Dairy Science, 72, 68-78. https://doi.org/10.3168/jds.S0022-0302(89)79081-0

[23] Lean, I.J., Edmonson, A.J. and Versteeg, J. (1989) Body Condition Scoring of Dairy Cattle. In: Belschner, A., Ed., Animal Health Division, The Upjohn Company, Kalamazoo, Article ID: 49001.

[24] Heinrichs, A.J. and Ishler, V.A. (2011) Body Condition Scoring as a Tool for Dairy Herd Management, Extension Circular 363. In: Jones, C. and Heinrishs, J., Eds., Proceeding Manual for Body Condition Scoring, Department of Dairy and Animal Sciences Pennsylvania State University, University Park, 1-14.

[25] Erb, H.N., Smith, R.D., Oltenacu, P.A., Guard, C.L., Hillman, R.B. and Powers, P.A. (1985) Path Model of Reproductive Disorders and Performance, Milk Fever, Mastitis, Milk Yield and Culling in Holstein Cows. Journal of Dairy Science, 68, 3337-3349. https://doi.org/10.3168/jds.S0022-0302(85)81244-3 
[26] Ruegg, P.L., Goodger, W.J., Holmberg, C.A., Weaver, L.D. and Huffman, E.M. (1992) Relation among Body Condition Score, Milk Production and Serum Urea Nitrogen and Cholesterol Concentrations in High-Producing Holstein Dairy Cows in Early Lactation. American Journal in Veterinary Research, 53, 10-14.

[27] Montiel, F. (2001) Actividadovárica post-partoenbovinos de doblepropósitoen el trópicohúmedomexicano. Doctoral Thesis, Dicision De Estudios De Posgrado E Investigacion Facultad De Medicina Veterinfaria Y Zootecnia. Universidad Nacional Autonoma De Mexico.

[28] Tucker, C.B., Rogers, A.R., Verkerk, G.A., Kendall, P.E., Webster, J.R. and Matthews, L.R. (2007) Effects of Shelter and Body Condition on the Behavior and Physiology of Dairy Cattle in Winter. Applied Animal Behavior Science, 105, 1-13. https://doi.org/10.1016/j.applanim.2006.06.009

[29] Gearhart, M.A., Curtis, C.R., Erb, H.N., Smith, R.D., Sniffen, C.J., Chase, L.E. and Cooper, M.D. (1990) Relationship of Changes in Condition Score to Cow Health in Holsteins. Journal of Dairy Science, 73, 3132-3140. https://doi.org/10.3168/jds.S0022-0302(90)79002-9

[30] Byers, D.I. (1999) Practical On-Farm Suggestion for Managing Body Condition, Dry Matter Intake for Optimum Production, Reproduction and Health. Advances in Dairy Technology, 11, 153-169.

[31] Alapati, A., Sarjan, R.K., Suresh, J., Srinivasa, M.P.R. and Kotilinga, R.Y. (2010) Development of the Body Condition Score System in Murrah Buffaloes: Validation through Ultrasonic Assessment of Body Fat Reserves. Journal of Veterinary Science, 11, 1-8. https://doi.org/10.4142/jvs.2010.11.1.1

[32] Galina, C.S. and Arthur, G.H. (1989) Review of Cattle Reproduction in the Tropics. 2. Parturition and Calving Intervals. Animal Breeding Abstracts, 57, 679-686.

[33] Montiel, F. and Ahuja, C. (2005) Body Condition and Suckling as Factors Influencing the Duration of Postpartum Anestrus in Cattle: A Review. Animal Reproduction Science, 85, 1-26. https://doi.org/10.1016/j.anireprosci.2003.11.001

[34] Grummer, R.R., Mashek, D.G. and Hayirli, A. (2004) Dry Matter Intake and Energy Balance in the Transition Period. The Veterinary Clinics of North America. Food Animal Practice, 20, 447-470. https://doi.org/10.1016/j.cvfa.2004.06.013

[35] Jolly, P.D., McDougall, S., Fitzpatrick, L.A., Macmillan, K.L. and Entwistle, K.W. (1995) Physiological Effects of under Nutrition on Postpartum Anoestrus in Cows. Journal of Reproduction Fertility, 49, 477-492.

[36] Loeffler, S.H., De Vries, M.J., Schukken, Y.H., De Zeeuw, A.C., Dijkhuizen, A.A., De Graaf, F.M. and Brand, A. (1999) Use of AI Technical Scores for Body Condition, Uterine Tone and Uterine Discharge in a Model with Disease and Milk Production Parameters to Predict Pregnancy Risk at First AI in Holstein Dairy Cows. Theriogenology, 51, 1267-1284. https://doi.org/10.1016/S0093-691X(99)00071-0

[37] Laflamme, L.F. and Connor, M.L. (1992) Effect of Postpartum Nutrition and Cow Body Condition at Parturition on Subsequent Performance of Beef Cattle. Canadian Journal of Animal Science, 72, 843-851. https://doi.org/10.4141/cjas92-096

[38] Gaines, J. (1989) The Relationship between Nutrition and Fertility in Dairy Herds. Veterinary Clinics of North America: Food Animal Practice, 84, 997-1002.

[39] Ferguson, J.D. (1991) Nutrition and Reproduction in Dairy Cows. Veterinary Clinics of North America: Food Animal Practice, 7, 483-507.

[40] Roche, J.F. (2006) The Effect of Nutritional Management of the Dairy Cow on Reproductive Efficiency. Animal Reproduction Science, 96, 282-296.

https://doi.org/10.1016/j.anireprosci.2006.08.007 
[41] Mahjoubi, E., Amanlou, H., Zahmatkesh, D., Khan, M.G. and Aghaziarati, N. (2009) Use of Beet Pulp as a Replacement for Barley Grain to Manage Body Condition Score in Over-Conditioned Late Lactation Cows. Animal Feed Science and Technology, 153, 60-67. https://doi.org/10.1016/j.anifeedsci.2009.06.009

[42] Overton, T.R. and Waldron, M.R. (2004) Nutritional Management of Transition Dairy Cows: Strategies to Optimize Metabolic Health. Journal of Dairy Science, 87, 105-119. https://doi.org/10.3168/jds.S0022-0302(04)70066-1

[43] Frood, M.J. and Croxton, D. (1978) The Use of Condition Scoring in Dairy Cows and Its Relationship with Milk Yield and Live Weight. Animal Production, 27, 285-291. https://doi.org/10.1017/S0003356100036175

[44] Domecq, J.J., Skidmore, A.L., Lloyd, J.W. and Kaneene, J.B. (1997) Relationship between Body Condition Scores and Conception at First Artificial Insemination in a Large Dairy Herd of High Yielding Holstein Cows. Journal of Dairy Science, 80, 113-120. https://doi.org/10.3168/jds.S0022-0302(97)75918-6

[45] Wright, I.A. and Russel, A.J.F. (1986) The Use of Body Condition Scoring to Ration Beef Cows in Late Pregnancy. Animal Science, 43, 391-396.

https://doi.org/10.1017/S0003356100002610

[46] De Rouen, S.M., Franke, D.E., Morrison, D.G., Wyatt, W.E., Coombs, D.F., White, T.W., Humes, P.E. and Greene, B.B. (1994) Prepartum Body Condition and Weight Influences on Reproductive Performance of First-Calf Beef Cows. Journal of Animal Science, 72, 1119-1125. https://doi.org/10.2527/1994.7251119x

[47] Sinclair, K.D., Broadbent, P.J. and Hutchinson, J.S.M. (1994) The Effect of Pre- and Post-Partum Energy and Protein Supply on the Performance of Single and Twin-Suckling Beef Cows and Their Calves. Animal Science, 59, 379-389. https://doi.org/10.1017/S000335610000790X

[48] Morrison, D.G., Spitzer, J.C. and Perkins, J.L. (1999) Influence of Postpartum Body Condition Score Change on Reproduction in Multiparous Beef Cows Calving in Moderate Body Condition. Journal of Animal Science, 77, 1048-1054. https://doi.org/10.2527/1999.7751048x

[49] Duffield, T. (2000) Subclinical Ketosis in Lactating Dairy Cattle. Veterinary Clinic North America. Veterinary Clinics of North America: Food Animal Practice, 16, 231-253. https://doi.org/10.1016/S0749-0720(15)30103-1

[50] Gillund, P., Reksen, O., Grhn, Y.T. and Karlberg, K. (2001) Body Condition Related to Ketosis and Reproductive Performance in Norwegian Dairy Cows. Journal of Dairy Science, 84, 1390-1396. https://doi.org/10.3168/jds.S0022-0302(01)70170-1

[51] Markusfeld, O., Galon, N. and Ezra, E. (1997) Body Condition Score, Health, Yield and Fertility in Dairy Cows. Veterinary Records, 141, 67-72.

https://doi.org/10.1136/vr.141.3.67

[52] Kim, I.H. and Suh, G.H. (2003) Effect of the Amount of Body Condition Loss from the dry to Near Calving Periods on the Subsequent Body Condition Change, Occurrence of Postpartum Diseases, Metabolic Parameters and Reproductive Performance in Holstein Dairy Cows. Theriogenology, 60, 1445-1456.

https://doi.org/10.1016/S0093-691X(03)00135-3

[53] Grohn, Y.T. and Rajala-Schultz, P.J. (2000) Epidemiology of Reproductive Performance in Dairy Cows. Animal Reproduction Science, 60-61, 605-614. https://doi.org/10.1016/S0378-4320(00)00085-3

[54] Maizon, D.O., Oltenacu, P.A., Grohn, Y.T., Strawderman, R.L. and Emanuelson, U. (2004) Effects of Diseases on Reproductive Performance in Swedish Red and White Dairy Cattle. Preventive Veterinary Medicine, 66, 113-126. 
https://doi.org/10.1016/j.prevetmed.2004.09.002

[55] Butler, W.R. and Smith, R.D. (1989) Interrelationships between Energy Balance and Postpartum Reproductive Function in Dairy Cattle. Journal of Dairy Science, 72, 767-783. https://doi.org/10.3168/jds.S0022-0302(89)79169-4

[56] Hoedemaker, M., Prange, D. and Gundelach, Y. (2009) Body Condition Change Ante and Postpartum, Health and Reproductive Performance in German Holstein Cows. Reproduction in Domestic Animal, 44, 167-173. https://doi.org/10.1111/j.1439-0531.2007.00992.x

[57] Lopez-Gatius, F., Garcia-Ispierto, I., Santolaria, P., Yaniz, J., Nogareda, C. and Lopez-Bejar, M. (2005) Screening for High Fertility in High-Producing Dairy Cows. Theriogenology, 65, 1678-1689.

https://doi.org/10.1016/j.theriogenology.2005.09.027

[58] Nebel, R.L. and McGilliard, M.L. (1993) Interactions of High Milk Yield and Reproductive Performance in Dairy Cows. Journal of Dairy Science, 76, 3257-3268. https://doi.org/10.3168/jds.S0022-0302(93)77662-6

[59] Froment, P. (2007) Note detatcorporel et reproduction chezlavachelaitiere. Thesis, La Faculate De Medicine De Creteil, Ecole nationale Veterinaried, Altort.

[60] Ferret, S., Charbonnier, G., Congnard, V., Jeanguyot, N., Dubois, P., Levert, et al. (2005) Relationship between Oestrus Expression and Detection, Resumption of Cyclicity and Body Condition Losses in Postpartum Dairy Cows. Rencontresauftour des Recherches sur les Ruminant, 19, 149-152.

[61] Pivko, J., Makarevich, A.V., Kubovicova, E., Hegedusova, Z. and Louda, F. (2012) Histopathological Alterations in the Antral Ovarian Follicles in Dairy Cows with a Tendency to Emaciation. Histology and Histopathology, 27, 1211-1217.

[62] Bezdicek, J., Andrea, N., Alexender, M. and Elina, K. (2020) Relationship between the Animal Body Condition and Reproduction: The Biotechnological Aspects. Archives Animal Breeding, 63, 203-209. https://doi.org/10.5194/aab-63-203-2020

[63] Fallas, M.R., Zarco, Q.L., Galina, C.S. and Basurto, H. (1987) Efecto del amamantamientosobre la actividadováricapospartoenvacas F1 (Holstein $\times$ Indobrasil) en dos tipos de pasto. In: Instituto Nacional de Investigaciones Forestales, Agrícolas y Pecuarias, Ed., Reunión de Investigación Pecuariaen México, INIFAP (Instituto Nacional de Investigaciones Forestales, Agrícolas y Pecuarias), Mexico City, 348-349.

[64] Vaccaro, R. (1990) Comportamiento de bovinos para doble propósito en el trópico, Seminario Internacional sobre lechería Tropical. Villahernosa, Tabasco, México, 14-35.

[65] Galina, C.S. and Arthur, G.H. (1989) Review of Cattle Reproduction in the Tropics. 3. Puerperium. Animal Breeding Abstract, 57, 889-910.

[66] Williams, G.L. (1989) Modulation of Luteal Activity in Postpartum Beef Cows through Changes in Dietary Lipid. Journal of Animal Science, 67, 785-793. https://doi.org/10.2527/jas1989.673785x

[67] Wright, I.A., Rhind, S.M., Russel, A.J.F., Whyte, T.K., McBean, A.J. and McMillen, S.R. (1987) Effects of Body Condition, Food Intake and Temporary Calf Separation on the Duration of the Post-Partum Anoestrus Period and Associated LH, FSH and Prolactin Concentrations in Beef Cows. Animal Science, 45, 395-402. https://doi.org/10.1017/S0003356100002889

[68] Waltner, S.S., McNamara, J.P. and Hillers, J.K. (1993) Relationships of Body Condition Score to Production Variables in High Producing Holstein Dairy Cattle. Journal of Dairy Science, 76, 3410-3419.

https://doi.org/10.3168/jds.S0022-0302(93)77679-1 
[69] Butler, W.R., Everett, R.W. and Coppock, C.E. (1981) The Relationships between Energy Balance, Milk Production and Ovulation in Postpartum Holstein Cows. Journal of Animal Science, 53, 742-748. https://doi.org/10.2527/jas1981.533742x

[70] Allrich, R.D., Berghorn, K.A. and Noller, C.H. (1987) Influence of Energy Balance on Ovarian Activity and Estrus Behaviour in Postpartum Dairy Cows. Journal of Dairy Science, 7, 184.

[71] Villa-Godoy, A., Hughes, T.L., Emery, R.S., Chapin, L.T. and Fogwell, R.L. (1988) Association between Energy Balance and Luteal Function in Lactating Dairy Cows. Journal of Dairy Science, 71, 1063-1072. https://doi.org/10.3168/jds.S0022-0302(88)79653-8

[72] Spicer, L.G., Tucker, W.R. and Adams, G.D. (1990) Insulin-Like Growth Factor-1 in Dairy Cows: Relationships among Energy Balance, Body Condition, Ovarian Activity and Estrus Behaviour. Journal of Dairy Science, 73, 927-937. https://doi.org/10.3168/jds.S0022-0302(90)78749-8

[73] Lucy, M.C., Savio, J.D., Badinga, L., De La Sota, R.L. and Thatcher, W.W. (1992) Factors that Affect Ovarian Follicular Dynamics in Cattle. Journal of Animal Science, 70, 3615-3626. https://doi.org/10.2527/1992.70113615x

[74] Prado, R., Rhind, S.M., Wright, I.A., Russel, A.J.F., McMillen, S.R., Smith, A.J. and McNeilly, A.S. (1990) Ovarian Follicle Populations, Steroidogenicity and Micromorphology at 5 and 9 Weeks Post Partum in Beef Cows in two Levels of Body Condition. Animal Science, 51, 103-108. https://doi.org/10.1017/S0003356100005195

[75] Shresthaa, H.K., Toshihiko, N., Suzukic, T., Akita, M. and Higaki, T. (2005) Relationships between Body Condition Score, Body Weight and Some Nutritional Parameters in Plasma and Resumption of Ovarian Cyclicity Postpartum during Pre-Service Period in High-Producing Dairy Cows in a Subtropical Region in Japan. Theriogenology, 64, 855-866. https://doi.org/10.1016/j.theriogenology.2004.12.007

[76] Canfield, R.W., Sniffen, C.J. and Butler, W.R. (1990) Effects of Excess Degradable Protein on Postpartum Reproduction and Energy Balance in Dairy Cattle. Journal of Dairy Science, 73, 2342-2349. https://doi.org/10.3168/jds.S0022-0302(90)78916-3

[77] Canfield, R.W. and Butler, W.R. (1991) Energy Balance, First Ovulation and the Effects of Naloxone on LH Secretion in Early Postpartum Dairy Cows. Journal of Animal Science, 69, 740-746. https://doi.org/10.2527/1991.692740x

[78] Centurion-Castro, F., Orihuela-Porcayo, J., Ake-Lopez, R.J., Magana-Monforte, J.G., Montes-Perez, R.C. and Segura-Correa, J.C. (2013) Effect of Body Condition Score on Estrus and Ovarian Function Characteristics of Synchronized Beef-Master Cows. Tropical and Subtropical Agroecosystems, 16, 193-199.

[79] Armstrong, D.G, McEvoy, T.G, Batter, G., Robinson, J.J., Hogg, C.C., Woad, K.J. and Webb, R. (2001) Effect of Dietary Energy and Protein on Bovine Follicular Dynamics and Embryo Production in Vitro: Association with the Ovarian Insulin-Like Growth Factor System. Biology of Reproduction, 64, 1624-1632.

https://doi.org/10.1095/biolreprod64.6.1624

[80] Rhodes, F.M., De'ath, G. and Entwistle, K.W. (1995) Animal and Temporal Effects on Ovarian Follicular Dynamics in Brahman Heifers. Animal Reproduction Science, 38, 256-277. https://doi.org/10.1016/0378-4320(94)01375-V

[81] Sa Filho, M.F., Crespilho, A.M., Santos, J.E., Perri, G.A. and Baruselli, P.S. (2010) Ovarian Follicle Diameter at Timed Insemination and Estrous Response Influence of Ovulation and Pregnancy Likelihood after Estrus Synchronization with Progesterone and Progestin Based Protocols in Suckuled Bos indicus Cows. Animal Re- 
production Science, 120, 23-30. https://doi.org/10.1016/j.anireprosci.2010.03.007

[82] Rasby, R.J., Wettemann, R.P., Harms, P.G., Lusby, K.S. and Wagner, J.J. (1992) GnrH in the Infundibular Stalk-Medium Eminence Is Related to Percentage Body Fat in Carcasses of Beef Cows. Domestic Animals. Endocrinology, 9, 71-76. https://doi.org/10.1016/0739-7240(92)90010-U

[83] Zurek, E., Foxcroft, O.R. and Kennelly, J.J. (1995) Metabolic Status and Interval to First Ovulation in Postpartum Dairy Cows. Journal of Dairy Science, 78, 1909-1920. https://doi.org/10.3168/jds.S0022-0302(95)76816-3

[84] Dubub, J., Duffield, T.F., Leslie, K.E., Walton, J.S. and LeBlanc, S.J. (2012) Risk Factors and Effects of Postpartum Anovulation in Dairy Cows. Journal of Dairy Science, 95, 1845-1854. https://doi.org/10.3168/jds.2011-4781

[85] Bewley, J.M., Peacock, A.M., Lewis, O., Boyce, R.E., Roberts, D.J., Coffey, M.P., Kenyon, S.J. and Schutz, M.M. (2008) Potential for Estimation of Body Condition Scores in Dairy Cattle from Digital Images. Journal of Dairy Science, 91, 3439-3453. https://doi.org/10.3168/jds.2007-0836

[86] Loeffler, S.H., de Varies, M.J. and Schukken, Y.H. (1999) The Effects of Time of Disease Occurrence, Milk Yield, and Body Condition on Fertility of Dairy Cows. Journal of Dairy Science, 82, 2589-2604. https://doi.org/10.3168/jds.S0022-0302(99)75514-1

[87] Ferguson, J.D. and Otto, K.A. (2001) Managing Body Condition Scores in Dairy Cows. Proceeding of Intermountain Nutritional Conference, Salt Lake City, 65-82.

[88] Buckley, F., Sullivan, K.O., Mee, J.F., Evans, R.D. and Dillon, P. (2003) Relationships among Milk Yield, Body Condition, Cow Weight and Reproduction in Spring Calved Holstein-Friesians. Journal of Dairy Science, 86, 2308-2319. https://doi.org/10.3168/jds.S0022-0302(03)73823-5

[89] Roche, J.R., Macdonald, K.A., Burke, C.R., Lee, J.M. and Berry, D.P. (2007) Associations among Body Condition Score, Body Weight and Reproductive Performance in Seasonal-Calving Dairy Cattle. Journal of Dairy Science, 90, 376-391. https://doi.org/10.3168/jds.S0022-0302(07)72639-5

[90] Patton, J., Kenny, D.A., McNamara, S., Mee, J.F., O’Mara, F.P., Diskin, M.G. and Murphy, J.J. (2007) Relationships among Milk Production, Energy Balance, Plasma Analytes and Reproduction in Holstein-Friesian Cows. Journal of Dairy Science, 90, 649-658. https://doi.org/10.3168/jds.S0022-0302(07)71547-3

[91] Garnsworthy, P.C. and Topps, J.H. (1982) The Effect of Body Condition of Dairy Cows at Calving on Their Food Intake and Performance When Given Complete Diets. Animal Science, 35, 113-119. https://doi.org/10.1017/S0003356100000878

[92] Hegazy, M.A., Essawi, S.A. and Youssef, A.H. (1997) Relationship between Body Condition, Milk Yield and Reproductive Performance of Dairy Cows. Journal of veterinary Medicine, 45, 147-154.

[93] Braun, R.K., Donovan, G.A., Tran, T.Q., Mohammed, H.O. and Webb, D.W. (1987) Importance of Body Condition Scoring in Dairy Cattle. Bovine Production, 19, 122-126.

[94] Ruegg, P.L., Goodger, W.J., Holmberg, C.A., Weaver, L.D. and Huffman, E.M. (1992) Relation among Body Condition Score, Milk Production and Serum Urea Nitrogen and Cholesterol Concentrations in High-Producing Holstein Dairy Cows in Early Lactation. American Journal in Veterinary Research, 53, 10-14.

[95] Fagan, J.G., Bourke, S. and Roche, J.F. (1989) The Reproductive Performance of Dairy Cows in Five Herds. Irish Veterinary Journal, 42, 40-44. 
[96] Wathes, D.C., Fenwick, M., Cheng, Z., Bourne, N., Llewellyn, S., Morris, D.G., Kenny, D., Murphy, J. and Fitzpatrick, R. (2007) Influence of Negative Energy Balance on Cyclicity and Fertility in the High Producing Dairy Cow. Theriogenology, 68, S232-S241. https://doi.org/10.1016/j.theriogenology.2007.04.006 